\title{
Assessment of Shallow-Water Habitat Availability in Modified Dike Structures, Lower Missouri River, 2004
}

By Robert B. Jacobson, Caroline M. Elliott, and Harold E. Johnson, III

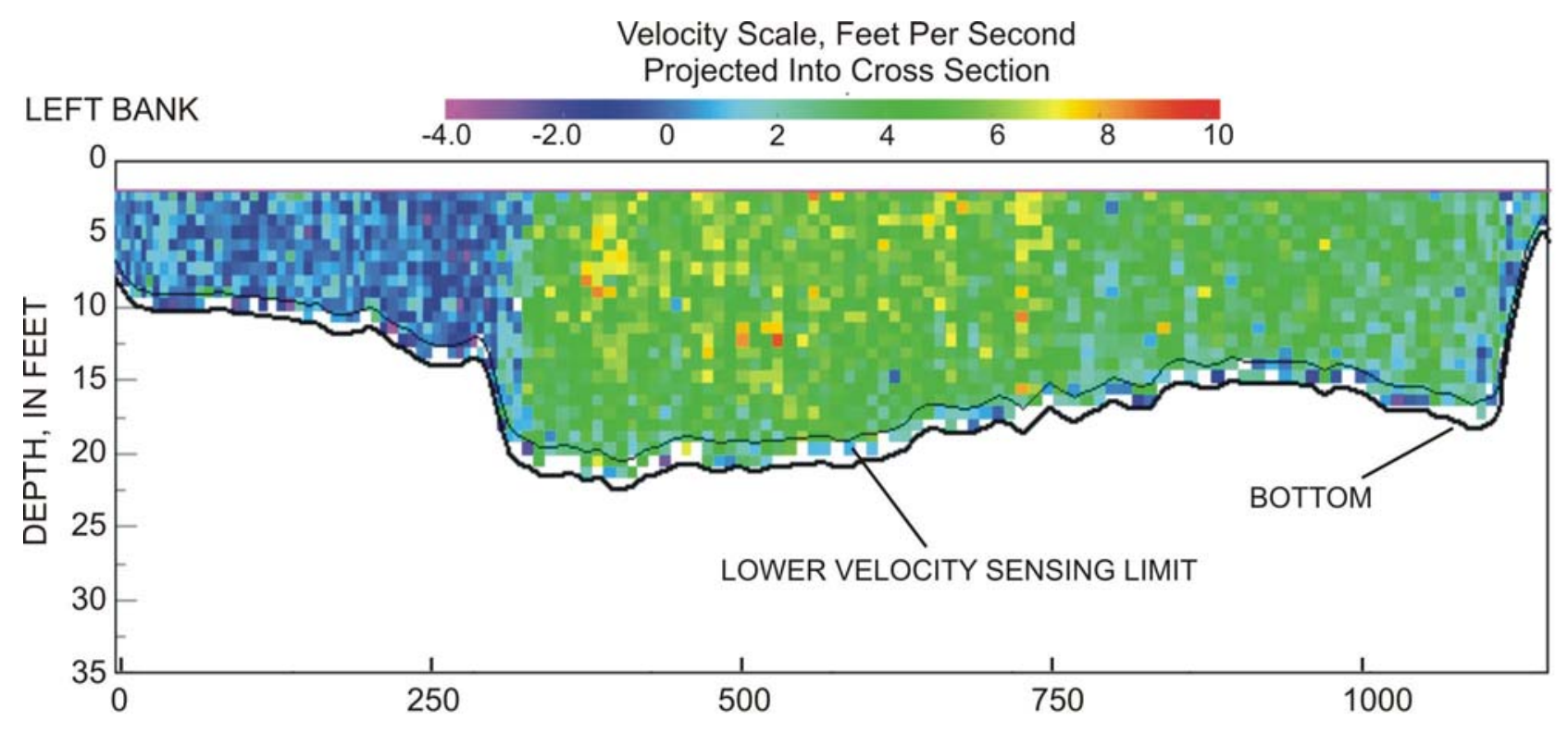

Any use of trade, firm, or product names is for descriptive purposes only and does not imply endorsement by the U.S. Government

\section{Open-File Report 2004-1409}




\section{U.S. Department of the Interior}

Gale A. Norton, Secretary

\section{U.S. Geological Survey \\ Charles G. Groat, Director}

U.S. Geological Survey, Reston, Virginia 2004

Revised and reprinted: 2004

For sale by U.S. Geological Survey, Information Services

Box 25286, Denver Federal Center

Denver, CO 80225

For more information about the USGS and its products:

Telephone: 1-888-ASK-USGS

World Wide Web: http://www.usgs.gov/

Although this report is in the public domain, permission must be secured from the individual copyright owners to reproduce any copyrighted material contained within this report. 


\section{Contents}

Figures.tes

\section{Figures}

1. Map showing location of shallow-water habitat evaluation sites and streamgages ............3

2. Hydrographs showing A. instantaneous discharges during 2004 surveys, and B. daily mean discharges from pre-modification surveys to post-modification

3. Graph showing example of differences in elevations calculated by two methods ............12

4. Graphs showing hypsometric curves, pre- and post-modification, and range of elevations corresponding to shallow-water habitat depth criteria. 


\section{Tables}

1. Locations, survey dates, and notes on dike modifications in this report

2. Construction reference plane elevations, flow quantiles, and water-surface elevations at streamflow gaging stations

3. Pre- and post-modification survey dates and prevailing discharges ................................

4. Comparison of discharge and stages quantiles using historical and modeled hydrologic

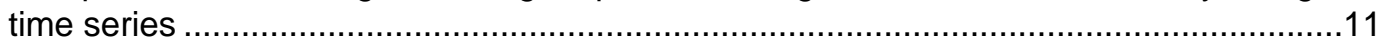

5. Estimated shallow-water habitat acreage for surveyed wing dike fields ........................15 


\section{Conversion Factors and Datums}

\begin{tabular}{|c|c|c|}
\hline Multiply & By & To obtain \\
\hline \multicolumn{3}{|c|}{ Length } \\
\hline inch (in.) & 2.54 & centimeter $(\mathrm{cm})$ \\
\hline inch (in.) & 25.4 & millimeter (mm) \\
\hline foot (ft) & 0.3048 & meter (m) \\
\hline mile (mi) & 1.609 & kilometer (km) \\
\hline \multicolumn{3}{|c|}{ Area } \\
\hline acre & 4,047 & square meter $\left(\mathrm{m}^{2}\right)$ \\
\hline acre & 0.4047 & hectare (ha) \\
\hline acre & 0.004047 & square kilometer $\left(\mathrm{km}^{2}\right)$ \\
\hline square mile $\left(\mathrm{mi}^{2}\right)$ & 259.0 & hectare (ha) \\
\hline square mile $\left(\mathrm{mi}^{2}\right)$ & 2.590 & square kilometer $\left(\mathrm{km}^{2}\right)$ \\
\hline \multicolumn{3}{|c|}{ Volume } \\
\hline gallon (gal) & 0.003785 & cubic meter $\left(\mathrm{m}^{3}\right)$ \\
\hline cubic foot $\left(\mathrm{ft}^{3}\right)$ & 0.02832 & cubic meter $\left(\mathrm{m}^{3}\right)$ \\
\hline cubic yard $\left(\mathrm{yd}^{3}\right)$ & 0.7646 & cubic meter $\left(\mathrm{m}^{3}\right)$ \\
\hline cubic mile $\left(\mathrm{mi}^{3}\right)$ & 4.168 & cubic kilometer $\left(\mathrm{km}^{3}\right)$ \\
\hline acre-foot (acre-ft) & 1,233 & cubic meter $\left(\mathrm{m}^{3}\right)$ \\
\hline \multicolumn{3}{|c|}{ Flow rate } \\
\hline acre-foot per day (acre-ft/d) & 0.01427 & cubic meter per second $\left(\mathrm{m}^{3} / \mathrm{s}\right)$ \\
\hline foot per second (ft/s) & 0.3048 & meter per second $(\mathrm{m} / \mathrm{s})$ \\
\hline cubic foot per second $\left(\mathrm{ft}^{3} / \mathrm{s}\right)$ & 0.02832 & cubic meter per second $\left(\mathrm{m}^{3} / \mathrm{s}\right)$ \\
\hline mile per hour (mi/h) & 1.609 & kilometer per hour (km/h) \\
\hline
\end{tabular}

Vertical coordinate information is referenced to the North American Vertical Datum of 1988 (NAVD 88). Horizontal coordinate information is referenced to the North American Datum of 1983 (NAD 83). Altitude, as used in this report, refers to distance above the vertical datum.

Conventional Units: Scientists writing about U.S. rivers face a dilemma because the scientific community expects adherence to the System International (S.I.) units of measure whereas managers and the public relate almost exclusively to conventional and customary units of measure. Because of the importance of communicating results to stakeholders in the Missouri River basin, this report presents discharges in customarily used units of cubic feet per second, and river locations in terms of river miles. Depths, other horizontal dimensions, and velocities, however, are presented in customary units with parenthetical S.I. equivalents. The conversion table above can be used to convert between additional units. River miles begin at 0 at the junction of the Missouri River with the Mississippi River at St. Louis, and increase in the upstream direction. Reference to left $(\mathrm{L})$ and right $(\mathrm{R})$ bank locations relate to direction while facing downstream. 
vi Shallow-Water Habitat, Lower Missouri River

Intentionally blank page 


\title{
Assessment of Shallow-Water Habitat Availability in Modified Dike Structures, Lower Missouri River, 2004
}

\author{
By Robert B. Jacobson, Caroline M. Elliott, and Harold E. Johnson
}

\section{Abstract}

This study documented the effects of wing-dike notching on the availability of shallow water habitat in the Lower Missouri River. Five wing dikes were surveyed in late May 2004 after they were notched in early May as part of shallow-water habitat (SWH) rehabilitation activities undertaken by the U.S. Army Corps of Engineers. Surveys included high-resolution hydroacoustic depth, velocity, and substrate mapping. Relations of bottom elevations within the wing dike fields to index discharges and water-surface elevations indicate that little habitat meeting the SWH definition was created immediately following notching. This result is not unexpected, as significant geomorphic adjustment may require large flow events. Depth, velocity, and substrate measurements in the post-rehabilitation time period provide baseline data for monitoring ongoing changes. Differences in elevation and substrate were noted at all sites. Most dike fields showed substantial aggradation and replacement of mud substrate with sandier sediment, although the changes did not result in increased availability of SWH at the index discharge. It is not known how much of the elevation and substrate changes can be attributed directly to notching and how much would result from normal sediment transport variation.

\section{Introduction}

During 2004, the U.S. Army Corps of Engineers accelerated channel morphology modifications on the Lower Missouri River to increase the availability of shallow-water habitat (SWH, operationally defined as water 0-5 feet deep and 0-2 feet/second current velocity). This work was carried out in coordination with the U.S. Fish and Wildlife Service in order to meet objectives outlined in the Missouri River Biological Opinion (U.S. Fish and Wildlife Service, 2000; 2003). Rehabilitation activities included construction of side-channel chutes, notching wing dikes, increasing channel top-width, and notching bank revetments.

Performance evaluations of the physical aspects of this activity rely on pre- and post-construction surveys to determine how rehabilitation has affected the availability and diversity of habitat. Habitat assessment should consider at least the main characteristics of physical aquatic habitat: depth, velocity, and substrate. In order to assess geomorphic adjustments to modification, surveys also should include accurate assessments of bottom topography.

\section{Shallow-water Habitat and the Lower Missouri River Ecosystem}

The Lower Missouri River channel morphology has been substantially changed compared to the historical condition. Clearing of woody debris and stabilization of the Missouri River began in the early 1800's to improve conditions for steamboat navigation. Most of the river's permanent engineering structures, however, are the direct result of the Missouri River Bank Stabilization and Navigation Project, part of the Pick-Sloan Act of 1944 (Ferrell, 1996). Wing dikes and revetments have stabilized the riverbanks, and narrowed and focused the thalweg to maintain a self-dredging navigation channel from St. Louis, Missouri, 735 miles (1,200 km [kilometers]) upstream to Sioux City, Iowa. The result has been to create a narrow, swift, and deep channel from what was historically a shallow, shifting, braided river. Riverine habitat loss has been estimated as much as 100,000 acres (about $400 \mathrm{~km}^{2}$ [square kilometers]; Funk and Robinson, 1974; Hesse and Sheets, 1993). Recognition of the scope of habitat loss has increased interest in rehabilitating parts of the Missouri River (Latka and others, 1993).

Ecologists generally accept the premise that physical habitat is a central factor in organizing aquatic ecosystems (Gorman and Karr, 1978; Schlosser, 1987; Power and others, 1988; Jeffries and Mills, 1990). Factors 
other than physical habitat (for example, nutrients, energy, competition with invasive species, or contaminants) are also potentially important in determining ecosystem functions. However, most management emphasis on the Lower Missouri River (St. Louis, Missouri to Yankton, South Dakota; fig. 1) has been on physical habitat because of the magnitude of change and the direct connection of physical habitat to management actions (U.S. Fish and Wildlife Service, 2000; 2003; U.S. Army Corps of Engineers, 2004).

Evaluations of physical habitat rehabilitation on the Lower Missouri River mainstem currently concentrate on a single measure of physical habitat: areas of shallow and slow water, known as shallow-water habitat (SWH). It is widely accepted that survival and growth of young fish are associated with the availability of shallow water with slow velocity (see for example, Scheidegger and Bain, 1995; Bowen and others, 1998; Freeman and others, 2001). The exact bounds of depth and velocity that are optimal as an index for habitat evaluation, however, vary among studies. Bowen and others (2003), for example, use water less than $3.2 \mathrm{ft}(1 \mathrm{~m})$ deep and current velocities less than $0.8 \mathrm{ft} / \mathrm{s}(0.25 \mathrm{~m} / \mathrm{s})$. On the Missouri River, habitat analysis has concentrated on a definition of SWH as $0-5$ $\mathrm{ft}(0-1.5 \mathrm{~m})$ and $0-2 \mathrm{ft} / \mathrm{s}(0-0.6 \mathrm{~m} / \mathrm{s})$ (U.S. Fish and Wildlife Service, 2000) . Although complex interactions among water properties, substrate, topography, and biota cannot be fully described by this one habitat class, it serves as a useful index of functional habitat.

As part of efforts to mitigate habitat losses and to recover native species, the U.S. Army Corps of Engineers embarked during Spring 2004 on a program to create 1,200 acres (486 hectares) of new SWH by early Summer. The dominant measures to create more SWH in the 2004 program were notching of wing dikes and banks, and construction of side-channel chutes. Dike modifications documented in this report were completed in May 2004; dike notches represent a relatively small part of the total SWH effort.

\section{Purpose and Scope}

Our analysis focuses on five wing-dikes that were notched during early May 2004, and for which we had pre-modification habitat surveys that were collected for other purposes (table 1, fig. 1). The objective of the study is to evaluate the effects of modifications on SWH availability, and to provide baseline information to use for evaluation of long-term habitat changes resulting from ongoing geomorphic adjustment.

Table 1. Locations and notes on surveyed, modified structures. Notch dimensions are widths; notches were excavated nominally to $4 \mathrm{ft}$ below the construction reference plane (75\% exceedance water surface). Structures were modified during April and May, 2004.

[GPS, global positioning system; RTK, real-time kinematic]

\begin{tabular}{|c|c|c|c|c|c|}
\hline $\begin{array}{l}\text { River } \\
\text { Mile }\end{array}$ & $\begin{array}{l}\text { Structure } \\
\text { Number }\end{array}$ & $\begin{array}{l}\text { Early May } \\
2004 \\
\text { Modification }\end{array}$ & $\begin{array}{c}\text { Pre- } \\
\text { Modification } \\
\text { Survey Date }\end{array}$ & $\begin{array}{l}\text { Post- } \\
\text { Modification } \\
\text { Survey Date }\end{array}$ & Survey Notes \\
\hline 250.1 & D-260.3 & $50 \mathrm{ft}$ notch & $3 / 7 / 2002$ & $5 / 17 / 2004$ & $\begin{array}{l}\text { Grand River reach. Depth, velocity, } \\
\text { substrate; differential GPS, indirect } \\
\text { elevation control; } 15 \text { m transects. }\end{array}$ \\
\hline 222.5 & D-233.6 & $50 \mathrm{ft}$ notch & $7 / 11 / 2003$ & $5 / 25 / 2004$ & $\begin{array}{l}\text { Glasgow River reach. Depth, } \\
\text { elevation, velocity, substrate; RTK } \\
\text { GPS elevation control; } 40 \text { m transects }\end{array}$ \\
\hline 222.3 & D-233.4 & $50 \mathrm{ft}$ notch & $7 / 11 / 2003$ & $5 / 25 / 2004$ & $\begin{array}{l}\text { Glasgow River reach. Depth, } \\
\text { elevation, velocity, substrate; RTK } \\
\text { GPS elevation control; } 40 \text { and } 20 \text { m } \\
\text { transects }\end{array}$ \\
\hline 203.3 & R-212.3 & $\begin{array}{l}\text { Enlarge } \\
\text { existing } \\
\text { notch }\end{array}$ & $10 / 16 / 2003$ & $5 / 25 / 2004$ & $\begin{array}{l}\text { Lamine River reach. Depth, elevation, } \\
\text { velocity, substrate; RTK GPS elevation } \\
\text { control; irregular survey within } \\
\text { revetment area; } 20 \mathrm{~m} \text { transects } \\
\text { outside }\end{array}$ \\
\hline 201.1 & D-209.6 & $50 \mathrm{ft}$ notch & $10 / 10 / 2003$ & $5 / 25 / 2004$ & $\begin{array}{l}\text { Lamine River reach. Depth, elevation, } \\
\text { velocity, substrate; RTK GPS elevation } \\
\text { control; } 20 \mathrm{~m} \text { transects }\end{array}$ \\
\hline
\end{tabular}




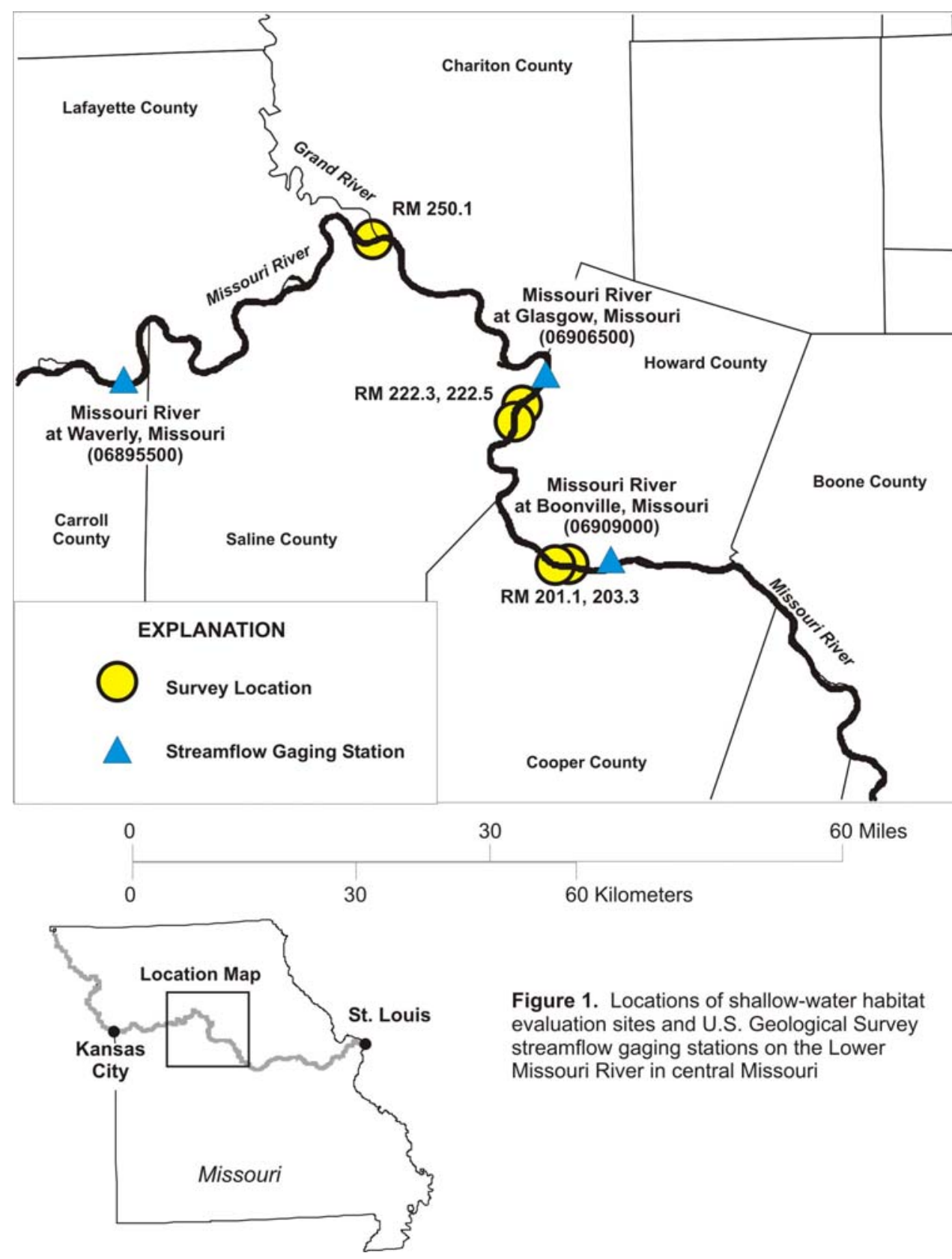

Our objective was to develop depth, velocity, substrate, and elevation maps of pre- and post-modification conditions. To assess habitat availability for the July 15 - August 15 index time frame identified in the 2003 Biological Opinion (U.S. Fish and Wildlife Service, 2003) it would have been preferable to assess habitat near the median flow of the index period during relatively steady discharge. Because of a deadline to demonstrate attainment of SWH acreage before July 2, 2004, mapping had to be completed and documented during a relatively short time frame (May 14, 2004 - June 4, 2004). Consequently, it was not possible to match the median flow or assure steady discharges (fig. 2). Therefore, depths and velocities reported here (and to a lesser extent, substrate) will not be strictly comparable to the index time frame. Because elevation changes are less dynamic, elevations may be more comparable to those expected during median discharges of the index time period. Similarly, it would have been preferred to match pre- and post-modification surveys to the same index discharges. However, as the premodification surveys were completed at various discharges before this study was anticipated, and given the highly dynamic discharge during the post-modification surveys, this also was not possible.

Maps included all wetted area of at least $1 \mathrm{ft}$ ( $0.3 \mathrm{~m}$ ) depth from just upstream of the modified wing dike, extending through the downstream area of influence of the wing dike, and from the near shoreline to the navigation 
line (or thalweg) as shown on USACE navigation charts. The downstream extent of wing dike influence was delineated by the adjacent, downstream wing-dike, or by the downstream limit of sandbar that was geometrically related to the dike. For quantitative comparison of habitat between pre- and post-modification surveys, we defined a Habitat Inventory Area (HIA), a rectangular box representative of the dike influenced area and common to both surveys.

\section{Approach and Methods}

The general approach to evaluating effects of modification was to map habitats in notched wing-dike areas using hydroacoustic instruments that were georeferenced using high-precision real-time kinematic global positioning system (RTK GPS). Maps will allow for characterization of habitat and provide baseline information for monitoring and assessment of changes. English and Systeme Internationale (SI) measurement units are emphasized in this report to facilitate communications with managers, stakeholders, and the public. English units are the customarily used in management decisions, legal discussions, and by the public. Readers are referred to the conversion table to convert between units.

\section{Hydrology}

The 2003 Biological Opinion (U.S. Fish and Wildlife Service, 2003) establishes July 15 - August 15 as an index time frame for evaluation of SWH. We calculated median, 75\%, and25\% exceedance discharges (that is, daily mean discharges equaled or exceeded 50\%, 75\%, and 25\% of the time) for the index time frame using 1967 2003 historical records at U.S. Geological Survey (USGS) streamgaging stations at Waverly, Missouri (06895500) and Boonville, Missouri (06909000). The record at Glasgow is not of sufficient length to calculate quantiles reliably. The 1967-2003 timeframe covers the post-dam-closure hydrology of the Lower Missouri River, but quantiles calculated from the historical record may be biased - over the long term - by high flows of the 1990's. For reference, 75\%, 50\%, and 25\% flow exceedances at Boonville, Missouri, for the index period are shown on figure $2 \mathrm{~A}$.

\section{Hydroacoustic Mapping}

The effects of modification were addressed with hydroacoustic mapping on the dates shown in table 1. Hydroacoustic mapping used standard U.S. Geological Survey, Columbia Environmental Research Center (CERC) procedures (Elliott and others, 2004; Jacobson and others, 2002). Digital copies of navigation charts were used as base maps for transect design and real-time navigation using HyPack ${ }^{\circledR}$ (Coastal Oceanographics, Middlefield, Connecticut) navigation software. Sampling transects were constructed to cover areas adjacent to and downstream of notched dikes, and extending at least to the navigation line. Sampling transects were generated at $33 \mathrm{ft}$ (10 m) and $66 \mathrm{ft}(20 \mathrm{~m})$ spacing and oriented generally perpendicular to the channel thalweg. The transect spacing was selected to provide sufficient spatial coverage for creating continuous surface maps of depth, velocity, and substrate data given usual scales of variation of these characteristics. Transects were ended laterally when the depth became too shallow for the boat, at approximately $1 \mathrm{ft}(0.30 \mathrm{~m})$ depth.

All data were georeferenced in the field by a 12-channel RTK-GPS system, except for the pre-modification survey at river mile (RM) 250.1. The RM 250.1 survey was conducted in March 2002 using differential GPS (DGPS). The RTK-GPS produces positional data with horizontal and vertical accuracies to within $0.1 \mathrm{ft}(0.02 \mathrm{~m})$. The DGPS gives $\mathrm{x}$ and y positions to approximately $3 \mathrm{ft}(1 \mathrm{~m})$ accuracy; elevation accuracy of DGPS is not sufficient for mapping elevations (the March 2002 survey at RM 250.1 was intended only for depths). All GPS data were collected at 200 millisecond (ms) intervals, resulting in positions approximately every $1.0 \mathrm{ft}(0.3 \mathrm{~m})$ along each transect at typical boat speeds of $2-4$ knots (1-2 meters per second, m/s) during data collection. Boat speeds were typically maintained at 5 knots or less.

Bathymetric data were collected with an Hydrotrac ${ }^{\circledR}$ echo sounder (Odom Hydrographic Systems, Inc, Baton Rouge, LA) equipped with a $208 \mathrm{kHz}$ (kilohertz), $8^{\circ}$ transducer mounted over-the-side of the boat, directly below the GPS antenna. The echo sounder was calibrated by bar check to account for boat draft, blanking distance (distance just below transducer for which echo returns are not possible), and environmental conditions that could affect the speed of sound in water. Pitch and roll were not compensated; however, the boat was not operated under 
conditions with significant waves. The precision of the echosounder data is $0.1 \mathrm{ft}(0.03 \mathrm{~m})$. Bar check results indicate that, under favorable bottom conditions, the depth and elevation accuracy is approximately $0.23 \mathrm{ft}(0.07 \mathrm{~m})$.
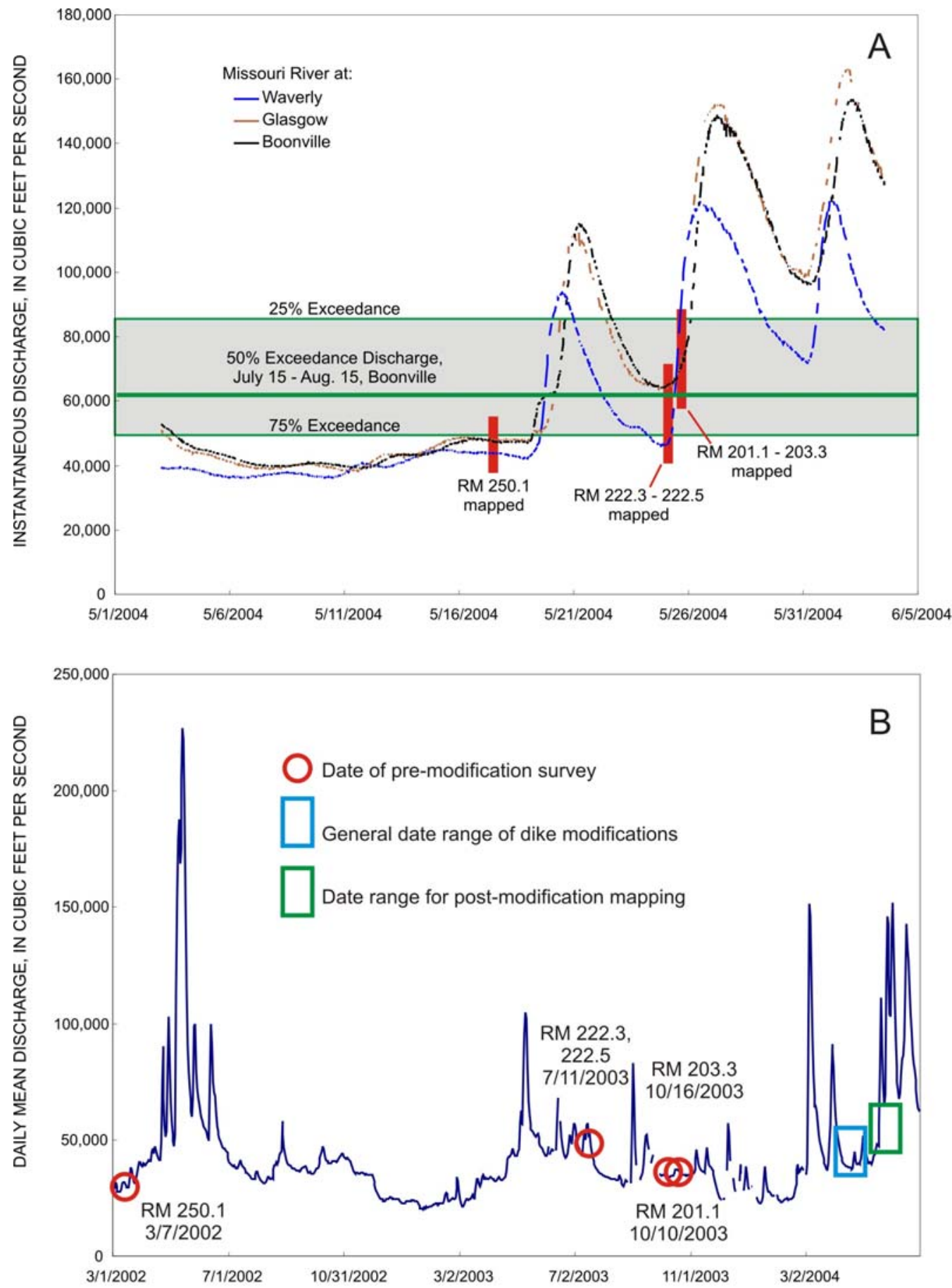

Figure 2. Hydrographs showing hydrologic context of wing-dike modifications and measurements. A. Hydrographs showing instantaneous discharges at three local U.S. Geological Survey streamflow gaging stations, and median and interquartile range of postregulation July 15 - August 15 discharges at Boonville, Missouri. Red bars indicate timing of habitat evaluation mapping. B. Hydrograph of daily mean discharges at Boonville, Missouri showing dates of pre- and post-modification surveys and timing of dike modifications. 
Bed material was classified into substrate classes using a RoxAnn ${ }^{\circledR}$ system (Stenmar Marine Microsystems, Aberdeen, Scotland), which uses the transducer output from the echosounder. The RoxAnn analyzes the shape of the acoustic signal returned from the river bottom to calculate two parameters related to roughness and hardness (e1 and e2) (see, for example, Rukavina, 1997). Depth, bed-material classification, and GPS positions were logged into standardized HyPack files.

Velocity data were collected with a Workhorse Rio Grande Model ${ }^{\circledR} 600 \mathrm{kHz}$ or $1200 \mathrm{kHz}$ acoustic Doppler current profiler (ADCP, RD Instruments, San Diego, California), depending on water depth conditions. These data also were georeferenced with RTK-GPS data, but were logged on a separate laptop computer running the WinRiver ADCP acquisition program. The ADCP was set up to collect 3-dimensional water velocity data in 0.8 $1.1 \mathrm{ft}(0.25-0.35-\mathrm{m})$ depth intervals (bins) from the surface to the bottom following generally accepted setup and operation procedures (Morlock, 1996). A column of bins (called an ensemble) was collected nominally every $2.5 \mathrm{~s}$ (seconds), resulting in an ensemble spacing that varied from approximately $8-33 \mathrm{ft}(2.5-10 \mathrm{~m})$ at typical boat speeds. For ADCP data collection, boat speeds were maintained below 5 knots, resulting in a maximum ensemble spacing of about $12 \mathrm{ft}(3.8 \mathrm{~m})$. The ADCP was internally calibrated for measured water temperature and compensates automatically for pitch and roll.

\section{Data Reduction and Maps}

Hydroacoustic data were reduced and compiled into maps of bathymetry (elevation and depth), substrate, and velocity. For purposes of comparison with previous data and analysis, the data were gridded to produce continuous surface maps.

\section{Bathymetry}

Water depth data were edited using a routine included with HyPack to remove spurious reflections from water-column turbulence, vegetation, or fish and to correct for places where bottom conditions prevented a good digitization of the echo. Elevations were obtained by calculating the orthometric height of the RTK antenna using the Geoid99 model and the NAVD88 vertical datum. Elevations of the channel bottom were then calculated by subtracting the distance from the antenna to the water surface, the calibrated draft of the echosounder transducer, and depth recorded by the echosounder from the antenna elevation. Following editing for accuracy and content, the datasets were exported from HyPack as comma-delimited files containing data of Universal Transverse Mercator (UTM) northing and easting, depth, elevation, and substrate for each data point.

A Perl software script (Practical Extraction and Report Language, ActiveState Corporation, Vancouver, British Columbia), was used to edit and format the comma-delimited files and prepare them for grid creation. Surfaces were interpolated using Surfer 7 ® (Golden Software, Inc., Golden Colorado) by kriging with a linear variogram model and zero anisotropy. An eight quadrant search was used against the 33 or $66 \mathrm{ft}$ (10 or 20 -meter) spacing of transects. Spurious data points were eliminated from consideration and the output grid resolution was set to $16 \mathrm{ft}$ (5-meter). A masking file was then used to clip the interpolated grid to the extent of the input data set. The Surfer 7 grids were exported as ASCII files and then added to an ArcView ${ }^{\circledR}$ (version 3.3, Environmental Systems Research Institute, Inc, Redlands, California) project as a table. Each table was added to a view as a point event theme and converted to a $16 \mathrm{ft}(5-\mathrm{m})$ grid.

For the RM 250.1 site, channel elevations were calculated indirectly by reference to an estimated watersurface elevation. Offsets of water-surface elevations from the construction reference plane (CRP) were calculated for the streamgages at Waverly and Glasgow on the day of survey. The CRP is an imaginary sloping plane that approximates the water-surface elevation of average low flows (nominally 75\% flow exceedance; U.S. Army Corps of Engineers, 2003). The slope of the CRP is constant between gages so CRP elevation can be interpolated at any distance along the river.

The offset (del-CRP) was apportioned along the channel by linearly prorating between the upstream (Waverly) offset and the downstream (Glasgow) offset. The prorated offset was added to the CRP elevation at RM 250.1, and converted from NGVD29 vertical datum to NAVD88. The del-CRP reference was also used to estimate stages associated with flow exceedances at each site; the inherent errors in this method are discussed in a later section. 


\section{Substrate}

Raw substrate roughness (e1) and hardness (e2) values were exported from HyPack. A Perl software script was then used to transform the raw e1 and e2 values by taking the square root and multiplying by 100 , resulting in integer data with near-normal probability distributions. The roughness $\left(\mathrm{e}_{1}\right)$ and hardness $\left(\mathrm{e}_{2}\right)$ values were imported into Surfer 7 for surface interpolation using 8-quadrant kriging.. These files were also clipped with a mask file, and imported as event themes and converted to 5-m grids in ArcView.

Grids for roughness, hardness, and depth were classified into four substrate classes using a multivariate unsupervised classification routine in ArcInfo ${ }^{\circledR}$ (version 8.3, Environmental Systems Research Institute, Inc., Redlands, California) (Elliott and others, 2004). Unsupervised classification was validated with a supervised classification based on ground-truth points encompassing the range of substrate types in the Lower Missouri River. Ground truth and interpretation of the unsupervised classification were developed through collection of sediment samples at shallow depths, and side-scan sonar imagery for areas of greater depth, in previous studies (Elliott and others, 2004).

\section{Velocity}

ADCP data were exported from WinRiver ${ }^{\circledR}$ (RD Instruments, San Diego, California) as ASCII-formatted files and reformatted with a Perl script for import into ArcView. The velocity magnitude, horizontal velocity direction, vertical velocity component, and position (easting, northing, and depth) were extracted for each individual bin during this reformatting step. A Perl software script also calculated the depth-average velocity for each ensemble (vertical collection of data). These data subsequently were imported into ArcView for 2D visualization. Mean water-column velocity magnitude data were imported to Surfer 7 , which interpolated data by kriging into 16.4-ft (5-m) intervals. The data were clipped with a mask file, imported in ArcView as an event theme and grids of mean velocity magnitude were produced with a 16-ft (5-m) cell size.

\section{Estimation of Elevation Quantiles}

A specific challenge in evaluating aquatic habitat is comparing sites, or a single site over time, in terms of the same hydrologic condition. Changes in habitat availability as a result of hydrologic variation (over a time frame where changes in topography due to sediment transport can be neglected) can be evaluated by one of three general methods:

1. Selection of an index discharge and measurement of habitat characteristics only during that discharge, plus/minus a nominal amount of variation as a practicality.

2. Measurement over a range of discharge to construct discharge-habitat area curves. Once discharge-habitat curves are constructed, habitat can be compared at any discharge or flow duration interpolated from the curve.

3. Hydraulic modeling to generate discharge-habitat curves.

In this study we attempted the first approach, but encountered practical difficulties because of the dynamic hydrologic situation over the compressed time frame of the study, and because the pre-modification surveys were prepared for other purposes before the need for the comparison study was appreciated.

All approaches share the practical need of estimating stage-discharge relations at the site of interest. Unless they can be developed by onsite survey, they will have to be estimated by relation to the CRP. For example, flow quantiles for the index period at each gage can be associated with a del-CRP at the gage, and the del-CRP can be apportioned along the river to the site of interest. Added to the CRP at the site (from CRP tables by river mile), the del-CRP for the flow quantiles provides an estimate of stages associated with specific discharges. The weaknesses in this method are that a) it assumes the CRP accurately reflects a constant flow duration datum along the river and b) it implicitly assumes an identical stage-discharge relation at every point along the river. While these assumptions may be sufficient for some bathymetric and engineering applications, the inherent errors in assumptions and interpolations may be substantial compared to the scale of habitat formation at rehabilitation sites, especially over short time intervals.

Table 2 shows flow quantiles for the index period at Waverly and Boonville gages, del-CRP values, and apportioned del-CRP values and associated water-surface elevations at the five wing dikes. The implications of using this method to estimate elevation quantiles are discussed in a later section. 
8 Shallow-Water Habitat, Lower Missouri River

Table 2. Construction Reference Plane (CRP) elevations, flow quantiles, and water-surface elevation quantiles for US Geological Survey streamflow gaging stations and wing-dike modification sites.

[ft, feet; cfs, cubic feet per second; NGVD29, National Geodetic Vertical Datum of 1929; NAVD88, North American Vertical Datum of 1988; Q25, flow equaled or exceeded $25 \%$ of the time, $25 \%$ flow exceedance; $Q_{50}, 50 \%$ flow exceedance; $Q_{75}, 75 \%$ flow exceedance]

\begin{tabular}{|c|c|c|c|c|c|c|c|c|c|c|c|}
\hline \multirow[b]{3}{*}{ Streamgage } & \multirow[b]{3}{*}{ River Mile } & \multirow{2}{*}{\multicolumn{2}{|c|}{ NGVD29 }} & \multirow{2}{*}{\multicolumn{2}{|c|}{ NAVD88 }} & \multicolumn{6}{|c|}{ July 15 - August 15} \\
\hline & & & & & & \multicolumn{3}{|c|}{ Discharge, in cfs } & \multicolumn{3}{|c|}{$\begin{array}{c}\text { Water Surface Elevation, } \\
\text { NAVD88 ft }\end{array}$} \\
\hline & & Gage Datum, ft & CRP & Gage Datum, ft & $\mathrm{CRP}, \mathrm{ft}$ & $\mathrm{Q}_{25}$ & $\mathrm{Q}_{50}$ & $\mathrm{Q}_{75}$ & $\mathrm{Q}_{25}$ & $\mathrm{Q}_{50}$ & $\mathrm{Q}_{75}$ \\
\hline \multirow[t]{5}{*}{ Boonville } & 197.1 & 565.42 & 574.30 & 565.52 & 574.40 & 86,500 & 65,500 & 49,700 & 580.22 & 577.29 & 574.86 \\
\hline & 201.1 & & 579.35 & & 579.49 & & & & 585.27 & 582.37 & 579.96 \\
\hline & 203.3 & & 579.52 & & 579.68 & & & & 585.44 & 582.56 & 580.16 \\
\hline & 222.3 & & 595.51 & & 595.60 & & & & 601.20 & 598.46 & 596.16 \\
\hline & 222.5 & & 595.68 & & 595.77 & & & & 601.37 & 598.63 & 596.33 \\
\hline \multirow[t]{2}{*}{ Glasgow } & 226.3 & 586.49 & 598.88 & 586.58 & 598.97 & & & & & & \\
\hline & 250.1 & & 619.41 & & 619.49 & & & & 624.85 & 622.30 & 620.15 \\
\hline Waverly & 293.4 & 646.00 & 656.90 & 646.34 & 657.24 & 78,200 & 60,900 & 47,500 & 661.03 & 658.11 & 655.68 \\
\hline
\end{tabular}




\section{Results}

Five wing dike areas previously surveyed for other purposes were resurveyed May $17^{\text {th }}$ and May $25^{\text {th }}, 2004$ (table 3). The results are grouped by geographic location, and discussed from upstream to downstream in the following sections.

Table 3. Survey dates and prevailing discharges.

[cfs, cubic feet per second]

\begin{tabular}{|c|c|c|c|c|c|}
\hline \multirow[b]{2}{*}{ Structure } & \multirow[b]{2}{*}{$\begin{array}{l}\text { River } \\
\text { Mile }\end{array}$} & \multicolumn{2}{|c|}{ Pre-Modification } & \multicolumn{2}{|c|}{ Post-Modification } \\
\hline & & Date & $\begin{array}{l}\text { Daily Mean } \\
\text { Boonville } \\
\text { Discharge, } \\
\text { cfs }\end{array}$ & Date & $\begin{array}{c}\text { Daily Mean } \\
\text { Boonville } \\
\text { Discharge, } \\
\text { cfs }^{*}\end{array}$ \\
\hline D-209.6 & 201.1 & $10 / 10 / 2003$ & 34,400 & $5 / 25 / 2004$ & 69,200 \\
\hline $\mathrm{R}-212.3$ & 203.3 & $10 / 16 / 2003$ & 37,400 & $5 / 25 / 2004$ & 69,200 \\
\hline D-233.4 & 222.3 & $7 / 11 / 2003$ & 53,700 & $5 / 25 / 2004$ & 69,200 \\
\hline D-233.6 & 222.5 & $7 / 11 / 2003$ & 53,700 & $5 / 25 / 2004$ & 69,200 \\
\hline D-260.3 & 250.1 & $3 / 7 / 2002$ & 27,700 & $5 / 17 / 2004$ & 47,600 \\
\hline
\end{tabular}

* Discharge at Boonville 5/25/2004 varied 66,000 - 73,000 cfs during survey

\section{Grand River Confluence Reach}

One dike was mapped on the river-right bank, just across from the Grand River confluence. Maps and cross sections from spur dike D-260.3 are found in the appendix. This dike was initially surveyed in March 2002 as part of a flathead catfish (Pylodictis olivaris) habitat-use study. Daily mean discharge at the time of the 2002 survey was 27,700 cfs at the Boonville gage, 25,600 cfs at the Glasgow gage, and 25,200 cfs at the Waverly gage. At this discharge, access to potential shallow-water areas was limited.

The 2002 topography of the D-260.3 dike field was dominated by a very large scour hole and an extensive sandbar downstream and toward the channel from the scour hole (fig. A.1). The sandbar was incompletely mapped in 2002. Depth maps from the two surveys document erosion of the bar and shifting of the thalweg from left bank to right between the two survey dates (figs. A.1 and A.5). Velocities within the HIA vary $0-5 \mathrm{ft} / \mathrm{s}(0-1.5 \mathrm{~m} / \mathrm{s})$; just within the "velocity shadow" of the wing dike, velocities are uniformly low for both surveys, mostly less than $1 \mathrm{ft} / \mathrm{s}(0.3 \mathrm{~m} / \mathrm{s})$ (figs. A.4, A.8). Between the two surveys, the high-velocity core in the main channel shifted substantially from the left bank to much closer to D260.3. ADCP cross sections also document that flow velocity behind the wing dikes was uniformly low (figs. A.9, A.10; cross sections in appendix are shown facing downstream, velocities projected into the plane of the section; negative velocities are upstream-directed, indicating recirculating flows). The 2004 ADCP cross section shows a small core of higher velocity that appears to relate to the notch location. The area of muddy sediment in the middle of the scour in 2002 had diminished in size by the time of the 2004 survey (fig. A.6). The scour now has sandy and rocky sediment in the center with muddy sediment extending downstream over the bar.

Elevation change at this site from 2002 to 2004 was dramatic. Shifting of the thalweg in the main channel from the left bank to the right bank (movement of the cross-over downstream) was associated with aggradation of as much as $10 \mathrm{ft}(3.0 \mathrm{~m})$ on the left channel margin and as much as $13 \mathrm{ft}(4.0 \mathrm{~m})$ in the center of the scour associated with D-260.3 (fig. A.11). The new thalweg position showed matching degradation of 6-8 ft (1.8-2.4 m), and erosion of the sandbar in the Grand River mouth resulted in local degradation of 14-16 ft (4.3-4.9 m) along the left bank. Shifting of the thalweg also was associated with lateral erosion of the sandbar downstream of D-260.3 and probably as much as $13 \mathrm{ft}(4.0 \mathrm{~m})$ of deposition in the D-260.3 scour. 


\section{Glasgow Reach}

Two adjacent spur dikes were mapped in the Glasgow Reach. Maps and cross sections from spur dikes D-233.4 and D-233.6 are found in the appendix. These dikes were initially surveyed in July 2003 as part of a pallid sturgeon (Scaphirhynchus albus) habitat-use study. Daily mean discharge during the 2003 survey was 53,700 cfs at the Boonville streamgage and 55,800 cfs at the Glasgow streamgage . This discharge was sufficient for good coverage of most shallow-water areas.

Dike fields D-233.4 and D-233.6 were treated as one mapped area because of their adjacency, but they are topographically very dissimilar (figs. A.12, A.16). The upstream dike has a persistent and prominent scour hole at the tip and just upstream whereas the downstream dike has a much more subdued scour at the tip. The upstream dike lacks a deep scour adjacent to the bank while the downstream dike has a very prominent scour adjacent to the bank. Substantial bar areas are developed downstream of both dikes. Velocities in both 2003 and 2004 surveys were dominantly less than $2.5 \mathrm{ft} / \mathrm{s}(0-0.76 \mathrm{~m} / \mathrm{s})$ behind the wing dikes (figs. A.15, A.19). A core of higher velocity $(2.5-3.5 \mathrm{ft} / \mathrm{s} ; 0.76-1.1 \mathrm{~m} / \mathrm{s})$ is apparent in the 2004 survey downstream of the notch in D-233.4; the core of high velocity may relate to the presence of the notch or the slightly higher discharge in 2004. Substrate in both dike fields in 2004 was substantially coarser than in 2003 (figs. A.13, A.17). It is not clear how much of the replacement of mud with sandier substrate results from differences in discharge alone and how much can be attributed to notching. A mudcovered bar detached from the shore in the D-233.4 field may have resulted from flow through the notch, resulting in a coarser channel between the bar and shore. This muddy patch does not conform to topographic contours, however. Elevation change maps document general aggradation of 0-3 ft (0-1 m) in both dike fields with some discrete areas of degradation 0-4 $\mathrm{ft}(0-1.2 \mathrm{~m})$.

\section{Lamine River Confluence Reach}

Two modified wing dikes were mapped in the Lamine River Reach. Maps and cross sections from spur dike D-209.6 and trailing dike R-212.3 are found in the appendix. These dikes were initially surveyed in October 2003 to construct a 2-dimensional hydraulic model of the Lamine River junction with the Missouri River. Daily mean discharges were 34,400 - 37,400 cfs (cubic feet per second) on the Boonville gage during the pre-modification survey. Spatial coverage was limited due to low water so some of the area downstream of D-209.6 was not mapped in 2003.

Trailing dike R-212.3 is an extension of revetment parallel to the shore. The aquatic area landward of the dike is extremely narrow but surprisingly deep (fig. A.25, A.29). A small scour hole existed near its upstream end in 2003, and a deep scour existed off the tip. In 2004, depths were more variable, and the 2004 elevation map confirms two prominent bar-like features. Velocities were uniformly low during the 2003 survey and remained less than $2.5 \mathrm{ft} / \mathrm{s}$ during the 2004 survey (figs. A.28, A.32). ADCP cross sections were not collected because of the narrow area and orientation of the area behind the dike. Substrate in 2003 was dominated by mud except for some sandy sediment in deep portion just upstream of the downstream L-head dike (fig. A.26). In 2004, the upstream area on the landward side of the dike was notably sandier than it was in 2003 (fig. A.30). The elevation change map documents areas of 2-4 $\mathrm{ft}(0.6-1.2 \mathrm{~m})$ aggradation behind the dike (fig. A.33). Conclusions about performance of this dike area should take into account the difficulty in mapping, gridding, and contouring data in the narrow area which may limit the resolution of the data.

Dike D-209.6 had relatively deep scours adjacent to the bank and off the tip in October 2003 (fig. A.34). A steep-sided sandbar existed downstream with a shallow secondary channel adjacent to the bank. These features persisted after the notching, but lack of coverage in 2003 limits analysis of change. Velocities in 2003 and 2004 were dominantly less than $4 \mathrm{ft} / \mathrm{s}$ in the HIA; differences between main channel and wing-dike velocities were greater at the higher discharges in 2004. Velocities in the protected area downstream of the wing dike were $0-2 \mathrm{ft} / \mathrm{s}(0-0.61 \mathrm{~m} / \mathrm{s})$. A small area of velocity maximum in 2004 near the junction of the dike with the bank appears to indicate the effect of the notch (fig. A.41). This effect is confirmed in the ADCP cross sections (figs. A.42, A.43). The 2004 cross section velocity profiles show greater diversity of velocity patterns within the dike field. A smaller area of mud substrate was mapped in the complex in 2004 than in 2003 (figs. A.35, A.39); it is not known whether this amount of change could 
have resulted from the notching or would be expected normally with discharge variation. The change map documents areas of as much as $3 \mathrm{ft}(1 \mathrm{~m})$ of aggradation in the parts of the wing-dike complex covered by maps from both surveys (fig. A.44).

\section{Discussion}

The following sections address challenges of inventorying and assessing changes in physical habitat in rehabilitation projects. Five issues identified are: determining reference flow regime, establishing elevation control, relating elevations in projects to flow duration, determining relevant monitoring time horizons, and evaluating velocities.

\section{Reference Flow Regime}

The 2003 Missouri River Biological Opinion (U.S. Fish and Wildlife Service, 2003) charges the Corps to evaluate SWH during July 15 to August 15 . The implication is that a particular flow exceedance or range of flows should be used to determine how much SWH exists during that time period. The specific flow exceedance and hydrologic time series for calculating flow duration were not specified. In absence of guidance, we have assumed median flow for the July 15 - August 15 index period. The median flow (and other flow exceedances) however will vary depending on the hydrologic time series used to calculate them.

For this study we used the historical, post-regulation 1967 - 2003 record for streamgages at Waverly and Boonville. An alternative would be to use output of the Corps' Daily Routing Model (DRM, U.S. Army Corps of Engineers, 1998) which synthesizes a long-term daily flow dataset for a subset of streamgages (including Boonville). The DRM provides 100 years of daily data 1898 - 1998, thereby modeling reservoir management scenarios over a wider range of hydroclimatic variability than available with historical data alone. The DRM flow exceedances are uniformly lower than the recent historical record because the DRM includes very dry years during the 1930's. Table 4 shows differences in flow and water-surface elevation quantiles for the index period comparing the historical record to the DRM MCP300, a specific flow regime scenario used to model the current (May 2004) water control plan. The differences in reference flow regime result in $0.7-1.6 \mathrm{ft}$ of differences stage at the streamgage. This amount of vertical variation in reference water-surface elevation could substantially alter SWH habitat inventories in some areas. Hence, future habitat assessment should specify the reference flow regime.

Table 4. Comparison of discharge and stage quantiles using historical 1967 - 2003 record and MCP300 1898 - 1998 daily routing model record (DRM), at Boonville, Missouri.

[cfs, cubic feet per second; ft, feet; $\mathrm{Q}_{25}$, flow equaled or exceeded $25 \%$ of the time, $25 \%$ flow exceedance; $\mathrm{Q}_{50}, 50 \%$ flow exceedance; $\mathrm{Q}_{75}, 75 \%$ flow exceedance]

\begin{tabular}{|c|c|c|c|c|c|c|}
\hline \multirow[b]{3}{*}{ Gage } & \multicolumn{6}{|c|}{ July 15 - August 15} \\
\hline & \multicolumn{3}{|c|}{ Discharge, in cfs } & \multicolumn{3}{|c|}{ Water Surface Elevation, $\mathrm{ft}$} \\
\hline & $\mathrm{Q}_{25}$ & $\mathrm{Q}_{50}$ & $\mathrm{Q}_{75}$ & $\mathrm{Q}_{25}$ & $\mathrm{Q}_{50}$ & $\mathrm{Q}_{75}$ \\
\hline Historical 1967 - 2003 & 86,500 & 65,500 & 49,700 & 580.22 & 577.29 & 574.86 \\
\hline МСР3001ㅜ $1898-1998$ & 81,200 & 55,300 & 40,200 & 579.51 & 575.74 & 573.31 \\
\hline Historical minus DRM & 5,300 & 10,200 & 9,500 & 0.71 & 1.55 & 1.56 \\
\hline
\end{tabular}

${ }^{1}$ U.S. Army Corps of Engineers daily routing model scenario used to model the current (May 2004) water control plan.

\section{Elevation Control}

The initial survey of dike D-260.3 at RM 250.1 lacked RTK-GPS elevation control and therefore water-surface elevations had to be estimated by reference to CRP (see Approach and Methods section). To estimate errors inherent with this method and the implications of comparing del-CRP elevation control with 
RTK-GPS, we calculated elevations at dikes D-209.6 (RM 201.1) and D-233.4/D-233.6 (RM 222.3-222.5) using both methods, and assessed differences by subtracting RTK-GPS gridded elevation dataset from the del-CRP elevation dataset (fig. 3). The subtraction involved exactly co-registered datasets, but because of spatial averaging involved with the gridding process, the errors should be viewed as spatially averaged errors. The mean difference for RM 201.1 was $1.8 \mathrm{ft}(0.55 \mathrm{~m}$, standard deviation, $0.5 \mathrm{ft}, 0.16 \mathrm{~m})$ and the mean difference for RM 222.3-222.5 was $-0.43 \mathrm{ft}(-0.13 \mathrm{~m}$, standard deviation, $0.06 \mathrm{ft}, 0.02 \mathrm{~m}$ ).

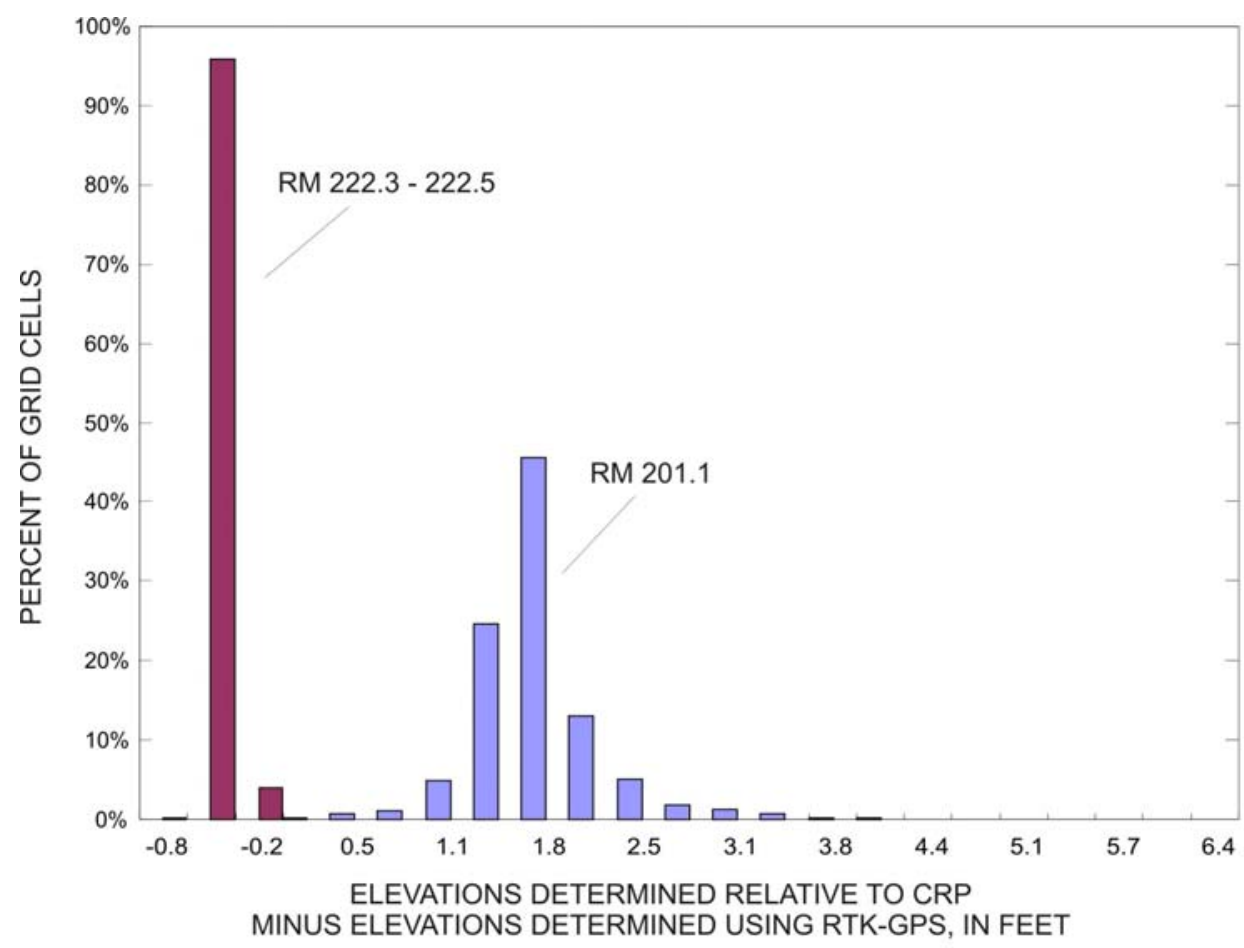

Figure 3. Histogram showing distribution of elevation errors calculated as del-CRP method minus RTK-GPS method for gridded elevation datasets of surveys on $5 / 25 / 2004$

Elevation accuracy of RTK-GPS in our method (combined ellipsoid height, echo-sounder, and random error) is estimated at $\pm 0.22 \mathrm{ft}(0.07 \mathrm{~m})$. Therefore, these comparisons indicate mainly errors associated with the del-CRP method. As discussed above, using offsets from CRP at streamgage sites for elevation control relies on assumptions that the CRP represents constant flow duration along the river and that stage-discharge relations along the channel do not vary significantly. The second assumption is particularly problematic for assessment of rehabilitation projects since a fundamental result of the rehabilitation activity is to change the local stage-discharge relation. An additional technical problem is estimating the del-CRP during a day when discharge varies substantially. This analysis suggests that elevation calculations using del-CRP may differ by as much as -0.6 to $+2.0 \mathrm{ft}(-0.2$ to $+0.6 \mathrm{~m})$ from actual elevations, which could be significant in assessing habitat acreage. Improved precision could be obtained by calculating and comparing elevations consistently using only one of the two methods, but as indicated by figure 3, the precision of the del-CRP method also varies among sites. The RTK-GPS method would consistently improve precision and accuracy.

\section{Water-Surface Elevation Quantiles and Habitat Extent}

Flow exceedance during the index time period needs to be estimated and translated to watersurface elevation at each rehabilitation site in order to assess sites on a constant hydrologic basis. Options 
for doing this involve either developing independent stage-discharge relations at each site or using offsets from CRP. If offsets from CRP are used, all of the assumptions and potential errors discussed above with respect to estimating elevation control also would apply to estimation of water-surface quantiles.

Figure 4 shows the cumulative areal distribution of elevations (hypsometric curve) for the Habitat Inventory Areas of dikes at RM 201.1, RM 222.3-222.5, and RM 250.1 (the trailing dike at RM 203.3 was omitted from the analysis because of its small size). The median and $75 \%$ flow exceedance quantiles are indicated, with shaded bands showing the water-surface elevation minus 5 feet ( $1.5 \mathrm{~m}$, the depth criterion for $\mathrm{SWH})$.

The hypsometric curve is a fundamental descriptor of the habitat availability at a site.

Rehabilitation activities presumably will serve to move the curves upward toward water-surface elevations associated with the index period. Flatter hypsometric curves in the $0-5 \mathrm{ft}(0-1.5 \mathrm{~m})$ range for the index flows will maximize SWH area. Gently sloping hypsometric curves indicate more elevation and depth diversity than flat curves.

On the hypsometric curves, the difference between the maximum bottom elevation and the index water-surface elevation indicates the area of emergent terrestrial habitat with the surveyed area. In all cases in this report, emergent terrestrial area is zero because discharges during the surveys were not sufficient to map higher surfaces on the margins of the dike fields; such areas are not extensive and were not directly affected by the modifications. The difference between the maximum bottom elevation and median watersurface elevation minus five feet indicates the area meeting the SWH depth criteria. By using a more liberal criterion and including all water-surface elevations between the $50 \%$ and $75 \%$ flow exceedances minus $5 \mathrm{ft}$, somewhat larger acreages are calculated (table 5). In all cases in this sample, however, the acreages are small, indicating that little SWH area exists at target flow elevations. Errors in estimating water-surface elevations for $75 \%$ and $50 \%$ flow exceedances on the order of -0.6 to $+2.0 \mathrm{ft}(-0.2 \mathrm{~m}$ to +0.6 $\mathrm{m})$ could significantly affect estimates of area meeting the SWH depth criterion.

Acreage calculations from hypsometric curves also can be influenced by the total area that can be surveyed at a given discharge. Our RM 201.1 (May 17, 2004) survey was at relatively low discharge and therefore bar areas attached to the right bank were not included. Surveys at higher discharge (like the May 25, 2004 surveys) include some additional area at higher elevations and may therefore measure additional habitat conforming to SWH index discharges, if higher elevation areas exist. Even for the low water survey at RM 250.1 on May 17, 2004, however, all the area that would be expected to be affected directly by recent dike notching was included in the survey. Nevertheless, these results emphasize that to map elevations conforming to SWH criteria at index discharges requires mapping at discharges somewhat higher than the index so all the potential habitat acreage can be traversed by the boat. Alternatively, combined boat and terrestrial surveys could be used to assure that all potential habitat elevations are mapped.

Hypsometric curves for pre- and post-modification surveys indicate geomorphic changes in the dike fields, and gains or losses in SWH for the index discharges (fig. 4). Comparison of hypsometric curves for two surveys is complicated by the fact that water level differences between the surveys may dictate that different total areas are surveyed. The hypsometric curves in figure 4 are calculated on the same HIA areal basis, but some of the area under water in 2004 was above water and not mappable in the pre-modification surveys. For the RM 201.1 dike, the hypsometric curves support the conclusion that there was net loss of areas at low elevations from October 10, 2003 to May 25, 2004. Lower water during the pre-modification survey prevents any conclusions about gain or loss of areas corresponding to the SWH depth criterion. For the RM 233.4 - 233.6 dikes, the pre-modification survey is very similar to postmodification up to approximately $593 \mathrm{ft}$; in this case as well, lower water level during the pre-modification survey mitigates against strong conclusions about gains or losses of SWH. At RM 250.1, loss of area less than $598 \mathrm{ft}$ elevation and gain in area greater than $602 \mathrm{ft}$ elevation is evident. However, these measured changes are below elevations that would be effective in producing SWH. 

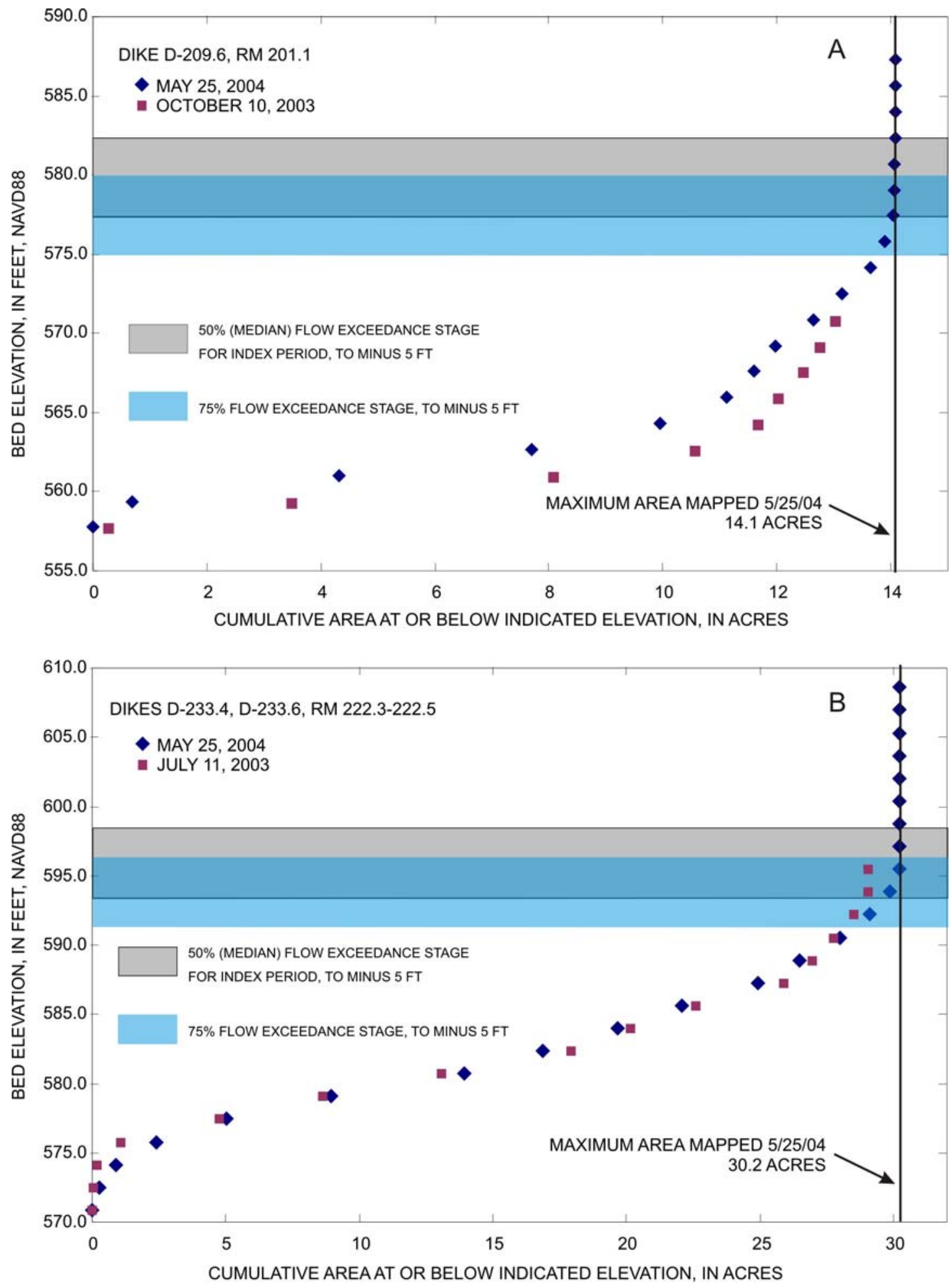

Figure 4. Hypsometric curves and estimated stages for discharge quantiles for four notched wing dikes, pre- and post-modification surveys. A. Dike near Lamine River junction. B. Combined adjacent dikes near Glasgow, Missouri 


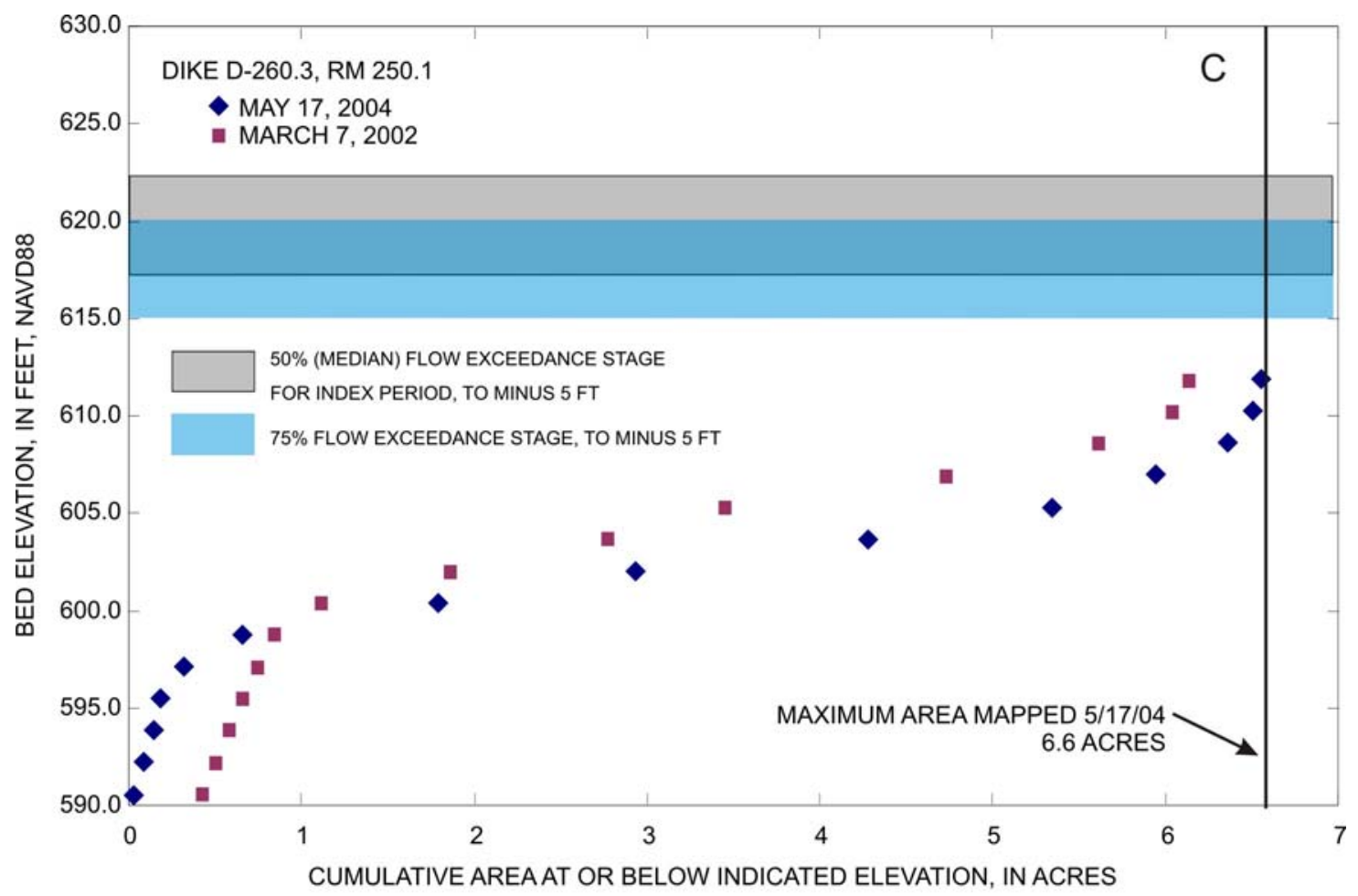

Figure 4 (cont.). Hypsometric curves and estimated stages for discharge quantiles for four notched wing dikes, pre- and post-modification surveys. C. Dike across from Grand River junction.

Table 5. Estimated SWH availability calculated from surveys on indicated dates, using $50 \%$ and $50-75 \%$ flow exceedances calculated for Boonville streamflow gaging station, historical record, 1967 - 2003. Availability estimate uses only depth criteria for SWH. [ft, feet]

\begin{tabular}{ccccc}
\hline & & & $\begin{array}{c}50 \% \\
\text { exceedance } \\
\text { minus 5 ft }\end{array}$ & $\begin{array}{c}50 \text { to } 75 \% \\
\text { exceedance } \\
\text { minus 5 ft }\end{array}$ \\
\cline { 3 - 5 } Structure & River Mile & Date & Availability, in acres \\
\hline D-209.6 & 201.1 & $5 / 25 / 2004$ & 0.03 & 0.29 \\
D-233.4-233.6 & $222.3-222.5$ & $5 / 25 / 2004$ & 0.39 & $1.73^{1}$ \\
D-260.3 & 250.1 & $5 / 17 / 2004$ & 0.00 & $0.00^{2}$ \\
\hline
\end{tabular}

\footnotetext{
${ }^{1}$ Combination of two dikes; average acreage per notched dike is 0.86 acres.

${ }^{2}$ Low water on the date of survey prevented survey of some areas on the margins of the dike field. These areas may provide some habitat according to the SWH criteria, but because the areas are far from the notches, it is unlikely they were affected by notching.
} 


\section{Monitoring Time Scales}

Geomorphic adjustments in rehabilitation projects require some amount of time before a presumptive dynamic equilibrium can be achieved, but empirical data and theory are lacking to estimate how long this time period is, and therefore how long monitoring should continue. As sediment transport is necessary for geomorphic adjustment, and sediment transport is typically a power function of discharge, high discharge events will probably be necessary to build SWH areas and move hypsometric curves upward. Habitat assessments before equilibration takes place will substantially underestimate the contribution of the project to ultimate available acreage. The surveys reported here took place within approximately one month of notching so opportunity for adjustment to high flows was very limited.

Whereas some period of time is necessary for measurable adjustment to take place, long periods between surveys my obscure changes resulting from engineered modifications and those attributable to background sediment-transport dynamics. Therefore, it is preferable to have a minimal time between the pre-modification survey and an initial post-modification survey. Additional post-modification surveys would be planned at increasing time intervals, and to capture effects of specific flood events, until adjustment to an equilibrium morphology is determined. This approach would minimize confounding effects of modification with background geomorphic variation.

Some sites may have unusually high rates of background geomorphic variation that would make them unsuitable for assessments. For example, the March 2002 survey at RM 250.1 was extremely different from the May 2004 survey. Some part of the measured aggradation and degradation may be due to mixing of del-CRP and RTK-GPS elevation calculations, perhaps as much as $2 \mathrm{ft}(0.7 \mathrm{~m})$. This error, however, cannot explain the mapped range of elevation change from +13 to $-13 \mathrm{ft}(+4$ to $-4 \mathrm{~m})$. In fact, the 2002 and 2004 maps document shifting of the thalweg of the main channel by as much as $390 \mathrm{ft}(120 \mathrm{~m})$ in this time interval. Because this site is at the junction of the Grand River with the Missouri, background geomorphic changes may be especially dynamic. Areas like this may not be well suited for isolating the effects of rehabilitation activities from background variation.

\section{Evaluating Depth and Velocity}

The definition of SWH is based on a range of depth and current velocity. Both of these quantities are highly sensitive to discharge, so evaluation of available habitat depends strongly on consistently conducting measurements at the index discharge, or within an accepted range. Depth distribution can be calculated relative to the bottom elevation using procedures discussed above, but current velocity must be measured at the index discharge unless effort is invested in multidimensional hydraulic modeling. Velocities were mapped in this study at discharges that poorly represent the median July 15 - August 15 flow because waiting for steady, targeted discharges was not an option. Velocity evaluations can be improved if sufficient time is available to measure target discharges.

An inherent tradeoff in the evaluation procedure is that high water improves ability to evaluate all possible elevation contributions to SWH, but target discharges are preferred to evaluate velocities. Surveys at stages where the survey boat can navigate over the wing dikes would also be able to measure notch geometries directly. This suggests that two types of assessment surveys could be considered: habitat surveys at specific target discharge ranges, and geomorphic surveys at higher water. The habitat surveys would assess whether the rehabilitation is performing in ways thought to support important species (that is, increasing the areal extent of habitat that conforms to the SWH definition) and the geomorphic surveys would track geomorphic adjustment of the project as sediment transport alters topography.

\section{Summary and Conclusions}

Five wing dikes were surveyed in May 2004 after notching as part of shallow-water habitat (SWH) rehabilitation activities carried out by the U.S. Army Corps of Engineers. Surveys included high- 
resolution hydroacoustic depth, velocity, and substrate mapping. Relations of bottom elevations within the wing dike fields to index discharges and water-surface elevations indicate that little SWH existed before or immediately after notching. This result is not unexpected, as significant geomorphic adjustment may require large flow events. Depth, velocity, and substrate measurements in the post-rehabilitation time period provide baseline data for monitoring ongoing changes. Differences in elevation and substrate between pre- and post-modification surveys were noted at all sites, supporting the idea that modifications have altered sediment transport and therefore may provide additional habitat meeting SWH criteria as time passes. Most dike fields documented substantial aggradation and replacement of mud substrate with sandier sediment. It is not known precisely how much of the elevation and substrate changes can be attributed directly to notching and how much would result from normal discharge variation. Comparisons of the May 2004 elevations with the pre-rehabilitation elevations demonstrate that significant change can occur (as much as $\pm 13 \mathrm{ft}$ ), but because of variable timing of pre-rehabilitation surveys, it is difficult to attribute change directly to notching. Whereas geomorphic changes associated with dike modifications can be surveyed over a range of discharges, and depths at target discharges can be estimated, evaluation of velocities requires surveys at or near the specific target discharges.

\section{References Cited}

Bowen, Z.H., Bovee, K.D., and Waddle, T.J., 2003, Effects of flow regulation on shallow-water habitat dynamics and floodplain connectivity: Transactions of the American Fisheries Society, v. 132, p. 809-823.

Bowen, Z.H., Freeman, M.C., and Bovee, K.D., 1998, Evaluation of generalized habitat criteria for assessing impacts of altered flow regimes on warmwater fishes: Transactions of the American Fisheries Society, v. 127, p. 455-468.

Elliott, C.M., Jacobson, R.B., and DeLonay, A.J., 2004, Physical aquatic habitat assessment, Fort Randall segment of the Missouri river, Nebraska and south Dakota: U.S. Geological Survey Open-File Report 2004-1060 80 p. On CD-ROM or online at: http://infolink.cr.usgs.gov/RSB/USGS_OFR_2004-1060/index.htm

Ferrell, John. 1996. Soundings - 100 years of the Missouri River Navigation Project: Kansas City, Mo., U.S. Army Corps of Engineers, $171 \mathrm{p}$.

Freeman, M.C., Bowen, Z.H., Bovee, K.D., and Irwin, E.R., 2001, Flow and habitat effects on juvenile fish abundance in natural and altered flow regimes: Ecological Applications, v. 11, p. 179-190.

Funk, J. L., and Robinson, J. W., 1974, Changes in the channel of the lower Missouri River and effects on fish and wildlife: Jefferson City, Mo., Missouri Department of Conservation, $52 \mathrm{p}$.

Gorman, O. T., and Karr, J. R., 1978, Habitat structure and stream fish communities: Ecology, v. 59, p. 507515.

Hesse, L.W., and Sheets, W., 1993, The Missouri River hydrosystem: Fisheries, v. 18, no. 5, p. 5-14.

Jacobson, R.B., Laustrup, M.L., and Reuter, J.M., 2002, Habitat assessment, Missouri River at Hermann, Missouri: U.S. Geological Survey Open-file Report 02-32, 22 p., 181 oversize maps. On CD-ROM or online at: http://www.cerc.usgs.gov/pubs/Moriver/herm_hab.htm.

Jeffries, M., and Mills, D., 1990, Freshwater Ecology: Principles and Applications: New York, Belhaven Press, $285 \mathrm{p}$.

Latka, D. C., Nesteler, J., and Hesse, L. W., 1993, Restoring physical habitat in the Missouri River: A historical perspective, in, Hesse, L. W., Stalnaker, C. B., Benson, N. G., and Zuboy, J. R., eds., Proceedings of the Symposium on Restoration Planning for the Rivers of the Mississippi River Ecosystem: National Biological Survey Biological Report 19, p. 350-359.

Morlock, S.E., 1996, Evaluation of acoustic Doppler current profiler measurements of river discharge: U.S. Geological Survey Water-Resources Investigations Report 95-4218, 37 p.

Power, M. E., Stout, R. J., Cushing, C. E., Harper, P.P., Hauer, F.R., Matthews, W.J., Moyle, P.B., Statzner, B., and Wais De Badgen, I.R., 1988, Biotic and abiotic controls in river and stream communities, Journal of the North American Benthological Society, v. 7, p. 456-479. 
Rukavina, N.A., 1997, Substrate mapping in the Great Lakes nearshore with a RoxAnn acoustic sea-bed classification system: in, Skafel, M.G., ed., Proceedings, Canadian Coastal Conference, Guelph,, Ontario, p. 338-349.

Schlosser, I. J., A conceptual framework for fish communities in small warmwater streams, in, Schlosser, I. J., ed., Community and Evolutionary Ecology of North American Stream Fishes: Norman, University of Oklahoma Press, p. 17-24, 269-299.

Scheidegger, K.J., and Bain, M.B., 1995, Larval fish distribution and microhabitat use in free-flowing and regulated rivers: Copeia, v. 1995, p. 125-135.

U.S. Army Corps of Engineers, 1998, Reservoir regulation studies - daily routing model studies: U.S. Army Corps of Engineers, Northwest Division Missouri River Region, Master Water Control Manual Missouri River Review and Update Study, v. 2A, 137 p.

U.S. Army Corps of Engineers, 2003, Supplemental Biological Assessment for the Current Water Control Plan - Appendix B - Detailed description of the Corps' alternative to the 2000 BiOP Gavins Point RPA: Portland, Oreg., US Army Corps of Engineers, Northwestern Division, 31 p.

U.S. Army Corps of Engineers, 2004, Summary Missouri River final environmental impact statement Master water control manual review and update: Portland, Oreg., Northwestern Division, U.S. Army Corps of Engineers, $33 \mathrm{p}$.

U.S. Fish and Wildlife Service, 2000, Biological Opinion on the Operation of the Missouri River Main Stem Reservoir System, Operation and Maintenance of the Missouri River Bank Stabilization and Navigation Project, and Operation of the Kansas River Reservoir System: Minneapolis, Minn., U.S. Fish and Wildlife Service, $286 \mathrm{p}$.

U.S. Fish and Wildlife Service, 2003, Amendment to the 2000 Biological Opinion on the Operation of the Missouri River Main Stem Reservoir system, Operation and Maintenance of the Missouri River Bank Stabilization and Navigation Project, and Operation of the Kansas River Reservoir System: Minneapolis, Minn., U.S. Fish and Wildlife Service, 298 p. 